\title{
LOS FABULISTAS ESPAÑOLES (Con especial referencia a los siglos XVIII y XIX)
}

M. ${ }^{2}$ Rosario Ozaeta

UNED

\section{RESUMEN}

Este artículo pretende ofrecer una panorámica de los cultivadores de la fábula en España, que parte de una sucinta trayectoria desde los orígenes hasta el siglo XVIII, para atender fundamentalmente al periodo comprendido entre este último siglo y el actual. Es patente el brillo alcanzado por el género durante la segunda mitad del siglo XVIII, debido a las circunstancias socioculturales e históricas que concurrieron en la centuria ilustrada, que lo favorecieron. De hecho, este florecimiento de la fábula hizo que se multiplicasen sus cultivadores en el siguiente siglo, en el que se mantiene la intención didáctica y moralizadora. Sólo en el siglo XX se aprecia un descenso en su actualidad, desapareciendo prácticamente la fábula y los fabulistas, aunque no sus cultivadores ocasionales, y manteniéndose el género residualmente en publicaciones infantiles, siempre bien aceptadas por sus receptores.

\section{INTRODUCCIÓN}

Este trabajo, sin pretender ser exhaustivo, trata de presentar una panorámica de los cultivadores de la fábula más significativos de cada siglo, mostrando cómo la respuesta de éstos en cuanto al tratamiento del género se en- 
cuentra estrechamente ligada a su contexto sociohistórico y cultural. De hecho, parámetros como el mayor o menor grado de inspiración en las fuentes, la originalidad, la actualidad, o la naturaleza de la fábula, son variables dependiendo de las etapas consideradas.

Es inevitable mencionar, al abordar este trabajo, la dificultad de definición de la fábula, lo que es reconocido unánimemente por los autores que le han dedicado su atención.

Según F. R. Adrados, representa un error pretender dar una definición "cerrada", ni aun tratándose de la antigua fábula. El autor, en su trabajo Historia de la fábula greco-latina, destaca las vacilaciones para denominar al género, desde la terminología primitiva hasta la vaguedad del latín Fabula y la del cultismo español «fábula». Adrados, para quien es éste «un género popular y tradicional, esencialmente 'abierto', que vive en infinitas variantes» (I, 1979:11), distingue entre la idea antigua y moderna de la fábula, señalando: «Nuestra idea de la fábula como un género animalístico procede de ciertas colecciones de época moderna: las de La Fontaine, Iriarte y Samaniego, entre otras. Efectivamente, estas colecciones crearon, a partir de los siglos XVII y XVIII, la idea moderna de la fábula» (ibid.: 32).

C. García Gual (1978) se hace eco igualmente de la aludida dificultad de definición, así como de la escasa consideración teórica dedicada al género - -dimanante, según su opinión, de la visión de la fábula como mero instrumento retórico y pedagógico-, hasta los teóricos alemanes del siglo XVIII. El autor, que examina diversos criterios, destaca los siguientes rasgos como inherentes del relato fabulístico: el carácter alegórico, la intención moral y la brevedad.

Tras esta breve presentación, pasamos a mostrar los cultivadores de la fábula en España a lo largo de los siglos y en particular en su época de florecimiento mayor, que se centra en los siglos XVIII y XIX. No nos referiremos a otras consideraciones teóricas relativas al origen, historia, caracterización u organización formal, que formarian parte de otro estudio y a las que han sido dedicadas numerosas investigaciones.

BREVE PRESENTACIÓN DEL PERÍODO COMPRENDIDO ENTRE LOS ORIGENES DE LA FÁBUla Y EL SIGLO XVIII

La fábula en España es de antigua tradición. Enrique Moreno Báez, en la Introducción de su versión española moderna de El Conde Lucanor, afirma:

El valerse de una historia, fábula o cuento para ilustrar las inteligencias es costumbre oriental, traída a España por nuestros moros. (1965: 9) 
La antiguiedad de la fábula en España se remonta a los siglos XII y XIII. Los cuentos que componen la Disciplina Clericalis, de origen oriental, que el judío Pedro Alfonso (Mosé Sefardí antes de su conversión) tradujo al latín ', datan del siglo XII, y la obra Calila e Dimna fue traducida al castellano bajo los auspicios de Alfonso X en 1257. En 1288 o 1289, el mallorquín Ramón Llull escribió el Llibre de meravelles, en el que se narran las aventuras de Félix a lo largo de diez Libros: «De Déu», «Dels àngels», «Del cel», «Dels elements», «De les plantes», «Dels metalls», «De les bèsties», «De l'home», «De paradís», «D'infern», y un capítulo final: «De la fi del llibre». Pues bien, el séptimo Libro, el «Llibre de les besties», incorporado de manera forzada en la obra según el criterio de Joaquim Molas, prologuista de la edición, es una fábula imaginativa sobre el poder -de inspiración oriental, en particular del Calila... y, presumiblemente, del Roman de Renard-, cuyos personajes animales satirizan con dureza la sociedad y la organización política de la época por medio de ejemplos que ponen de relieve la ambición humana. En la introducción del Llibre de les bèsties, publicación dedicada a dicho Libro, Jordi Rubió pone de manifiesto su carácter amargo y pesimista, y A. Llinarès destaca el carácter de compendio de principios morales y el valor de este documento, que refleja, bajo la apariencia de la ficción, la sociedad de fines del siglo XIII.

En la conocida obra del Infante Don Juan Manuel, El Conde Lucanor, Patronio, por medio de cuentos dialogados de la misma estructura, aleccionaba al conde. Estos cuentos son verdaderos apólogos en prosa, como el cuento II: «Lo que sucedió a un honrado labrador con su hijo», el cuento V: «Lo que sucedio a una zorra con un cuervo que tenía un pedazo de queso en el pico», o el cuento XXII: «Lo que sucedió al león y al toro», tanto en lo que respecta a su contenido, como a su carácter didáctico, como a su forma, que incluye una moraleja a modo de conclusión ${ }^{2}$.

Enrique Moreno Báez, en la Introducción de su versión -anteriomente citada - de la obra en cuestion, aporta noticias acerca de sus fuentes, según las cuales Don Juan Manuel continuaría la tradición oriental, siguiendo a la vez la tradición clásica y la realidad de su época.

Perteneciente igualmente al siglo XIV, el Libro de Buen Amor (1330) está salpicado de fábulas en verso que, en tono jocoso y moralizante, hacen que se haya considerado a Juan Ruiz, Arcipreste de Hita, como un precursor del

' El autor declara en el Prólogo: «Deus igitur in hoc opusculo mihi sit in auxilium, qui me librum hunc componere et in latinum transferre compulit.» (1948:1).

2 Según F. R. AdRados, en colecciones como la mencionada Disciplina Clericalis o como El Conde Lucanor, lo animalístico y lo no animalístico aparecen mezclados. 
género. F.C. Sainz de Robles, quien subraya la importancia de estas fábulas apoyándose en el estudio de M. de Puibusque («Origines de l'apologue espagnol»), situado al frente de la traducción del Conde Lucanor llevada a cabo por este último, y en el que traza el repertorio de fábulas contenidas en el $\mathbf{L i}$ bro de buen amor -consistente en treinta y un temas-, señala:

Las fábulas de nuestro Juan Ruiz no son ciertamente originales; sus modelos están en Pilpay, en Esopo, en Fedro; pero tiene nuestro Juan Ruiz tanta fuerza creadora, tales gracias poéticas, tanta sutileza para aclimatar a su época y a su patria las moralejas, que no se puede negar el mérito de la originalidad $(1964: 12)^{3}$

La influencia mencionada salta a la vista al revisar las estrofas de la obra: fábula de las ranas que pidieron rey a Júpiter (estrofas 199-205), ejemplo del perro y el trozo de carne reflejado en el agua (estrofas 226 y 227), ejemplo de la graja que se disfrazo de pavo real (estrofas 285-288), la raposa y el cuervo, de nuevo (estrofas 1437-1441):

La marfusa un día con la fambre andava; vido el cuervo negro en un árbol do estava: grand pedaço de queso en el pico levava; ella con su lisonja tan bien lo saludava...

Habría de pasar mucho tiempo desde aquí hasta que la fábula se asentara - por decirlo de algún modo- como género independiente en España ${ }^{4}$. Pues de hecho, tales historias continuaron apareciendo, pero sólo furtivamente, en la obra de grandes autores.

'En el mismo sentido se expresa María Bray Mariño, en el prólogo de la versión del Libro de buen amor, de la que es autora: «Poesía personalísima y original la de Juan Ruiz, a pesar de que sus cuentecillos sean de Isopete sacados, aunque los amores de doña Endrina y don Melón tengan su antecedente en la comedia Pamphilus, aunque don Camal y doña Cuaresma hayan tenido anteriores peleas, aunque la tienda de don Amor se parezca a otras ya descritas...» (1965:15). El profesor ADRADOS, por su parte, señala que los cuentos incluidos entre las fábulas de animales, así como las biografías realistas como la Vida de Esopo, dieron impulso a la cuentística medieval y a la picaresca: «En un autor como nuestro Arcipreste están presentes, en realidad, todos estos motivos y otros más» (1979: 14).

${ }^{4}$ Jesús María González. de Zárate, en la introducción de su interesante edición de Las Fábulas de Samaniego. Sus fuentes literarias y emblemáticas, alude, en su extensa biliografía, a la edición facsímil de E. CoTAREio sobre La vida del ysopet con sus fabulas hystoriadas (Hurus, 1489; ed. de Madrid 1929), que contiene a su vez un repertorio de literatura esópica editada en España, comprendiendo desde el siglo XV al XIX. GONZÁLEZ DE ZÁRATE menciona también en dicha introducción - que recomendamos a los estudiosos del género- a FERNANDO ARCE (Adagios y Fábulas, 1533) y a SEBASTIÁN MEY (Fabulario, 1613), así como a otros fabulistas vascos del siglo XIX: Bizenta y Juan Antonio Mogel, J.B. Archu, L. Goyehtche. A.P. Iturriaga, R. Artola. 
Citaré a algunos de ellos, a mi juicio los más notables del Siglo de Oro español, sin que ello suponga un demérito hacia la contribución de otros, como Pedro de Salas o A. Cubillo de Aragón, ambos de principios del siglo XVII. Otros autores incluyeron sus fábulas en obras pertenecientes a la literatura ascética, en crónicas, en poemas épicos, en comedias, colaborando igualmente al enriquecimiento del género. La obra Fábulas y cuentos en verso, preparada por María Goyri de Menéndez Pidal (selección, notas y glosario), ofrece un útil repertorio de autores - a pesar de no observar un orden cronológico-, ilustrado por fábulas de algunos de ellos.

Sobresalen enseguida, como indicaba, las grandes glorias. Félix Lope de Vega y Carpio incluía fábulas en Ja mayoría de sus comedias. Da fe de ello José Mallorquí, quien, en su obra Fábulas españolas, cita nueve de esos temas -refundidos de Esopo y Fedro-, a los que él denomina pasajes, no considerándolos propiamente fábulas, como por ejemplo: «El soberbio y el humilde», «La gata mujer», «El leñador y la muerte», "Contentarse con su estado», «El labrador, su hijo y el asno»... que no coinciden en su totalidad con los mencionados por María Goyri en la obra antes aludida, lo que confirma que el número de fábulas insertas por Lope fue amplio.

Tirso de Molina siguió el mismo método. Sainz de Robles cita la fábula de la zorra y el aliento fétido del león, «El león y la raposa», inserta en el primer Acto de El pretendiente al revés. María Goyri da además otros ejemplos, como «La mula y el doctor» $\mathrm{y}$ «El asno y el cochino».

Antonio Mira de Amescua incluyó la que sería célebre fábula $1^{a}$ del Libro I lafontainiano en la Jornada $3^{\mathrm{a}}$ de su obra Lo que le toca al valor -Duelo de honor y amistad-, lo que es registrado igualmente en los fabularios mencionados. Como la fábula es de todos conocida, expongo aquí los ágiles versos que la cierran:

\footnotetext{
...Mas la hormiga con gobierno

le respondió en canto llano:

- Pues cantaste en el verano,

danza, hermana en el invierno.
}

No hay que olvidar a Pedro Calderón de la Barca, ni a Francisco de Rojas Zorrilla, igualmente cultivadores del género.

Tampoco, andando el tiempo, a José de Cañizares, que incluye en una de sus obras la fábula «Lo cierto por lo dudoso» en la que — según un conocido tema-, un perro confunde la realidad con su propia imagen. Pero este último autor nos conduce ya hacia el siglo XVIII, en el que asistimos a un auténtico renacimiento de la fábula. 


\section{EL Siglo XVIII}

Alfonso I. Sotelo afirma con acierto en la Introducción a su edición de $F a ́$ bulas: «La fábula, que desde siempre fue un instrumento didáctico, se desarro1 ló ampliamente en el XVIII como género pragmático y de instrucción pública; florece ahora, cuando los escritores se sienten fascinados por los problemas de conducta moral y cuando la teoría literaria apoya y defiende la función didáctica del arte; el género decaerá cuando el público empiece a perder interés por las normas de conducta social y por los tipos sociales en cuanto desviados de esas mismas normas» (1997: 53).

Samaniego e Iriarte reinan en este siglo.

Además de la preocupación por la moral y la tendencia didactizante, el influjo francés en España s contribuyó al florecimiento de dicho género, notable en la segunda mitad del siglo XVIII. Samaniego contrajo una deuda -que no reconoció en su justa medida - para con La Fontaine, autor cuya lengua conocía bien, y con quien guardaba un claro paralelismo en muchos aspectos. En primer lugar, su epicureismo; su tono licencioso, de tinte enciclopedista, muy acorde con su momento, reflejado en sus cuentos. E. Jareño, en su edición de las Fábulas de Samaniego, afirma la inspiración de éste en los Cuentos de La Fontaine. R. J. Niess, por su parte, en su artículo: «La Fontaine and the Cuentos of Samaniego», se hacía eco de dicha inspiración — dejando a salvo la originalidad de Samaniego-, aunque atribuía una mayor delicadeza al autor francés.

Samaniego compartía también con su modelo un carácter pedagógico, que declara abiertamente en el Prólogo de sus fábulas:

Si en algo he empleado casi nimiamente mi atención, ha sido en hacer versos fáciles hasta acomodarios, según mi entender, a la comprensión de los muchachos. ${ }^{6}$

s A propósito de dicho influjo, he desarrollado dicho tema en otros estudios que se centran en la influencia de La Fontaine en los fabulistas españoles, a saber: Las traducciones castellanas de las Fábulas de La Fontaine durante el siglo XVIII (ed. en micoficha, Madrid, UNED, 1998); «Las fábulas de La Fontaine en el siglo XIX español», Coloquio SIHFLES 1997 sobre la recepción de autores franceses de la época clásica en los siglos XVIII y XIX en España y en el extranjero. Su utilización en la enseñanza del FLE (Ávila, 9-12 de oct. 1997), y en "Traducciones y adaptaciones en castellano de las fábulas de La Fontaine en el siglo XX», en el Coloquio sobre La Traducción de los clásicos franceses en la España del siglo XX (Univ. de Zaragoza, 17-18 de abril de 1997), los dos últimos en prensa.

- Fábulas. Ed. de Ernesto Jareño (1975:54). Esta cita ilustra la finalidad pedagógica de unas fábulas dedicadas a los alumnos del Real Seminario de Vergara. 
Como La Fontaine, Samaniego utilizó el verso libre, sirviéndose sobre todo de una combinación de endecasílabos y heptasílabos. El autor justificaba esta variedad de metros por su afán de huir del «monotonismo»...

...que adormece los sentidos y se opone a la varia armonía, que tanto deleita el ánimo y aviva la atención (Ibid.:55).

R. J Niess dedicó un artículo al heptasílabo de Samaniego, en el que se reafirmaba en la originalidad del autor español, y también en la idea de La Fontaine como modelo:

...it seems almost certain that Samaniego borrowed from him at least part of his technique (1941: 308).

No obstante, Samaniego, denominado «el La Fontaine español», quedaría por debajo de Iriarte en cuanto a riqueza de rima y de versificación; aunque ha habido opiniones muy encontradas al respecto.

Es indudable que Samaniego fue un modelo para sus contemporáneos, y con el renacer del género se multiplicaron las ediciones de sus fábulas en los siglos posteriores, tanto en España como fuera de ella ${ }^{7}$. Jareño ilustra dichos datos, y al mismo tiempo se hace eco de la decadencia sufrida por la obra del autor desde los años 40 del siglo XX, lamentando su ausencia en colecciones de tipo universitario de clásicos españoles, por creerle merecedor de un tratamiento más relevante dentro de la literatura comparada. A. I. Sotelo insiste en dicho olvido y en la escasa atención de la crítica, y llama la atención sobre los escasos lectores actuales de Samaniego en contraposición con el extensísimo número de ediciones de sus fábulas.

En Samaniego sobresalía ante todo un espíritu marcadamente europeísta -según Jareño-, que le hizo romper con la tradición fabulística medieval española, ignorándola ${ }^{8}$, y tomar sus obras directamente de algunos temas de Esopo, de Fedro, de La Fontaine y de John Gay, excepto el Libro IX, enteramente original. Así, la inspiración es variada en sus 157 fábulas; dichas fuentes se entremezclan a veces, mostrando un carácter de imitación muy propio de su siglo.

${ }^{7}$ Es de rigor la consulta de la Bibliografía de Autores Españoles del siglo XVIII, de F. AGUlLAR PIÑal, así como la Bibliografía incluida en la edición de González de Zárate, que ofrece algunas nuevas referencias.

* Según Emilio Martinez Mata, en su edición de Fábulas (1998: 34), dicha ignorancia se debería a la fecha de aparición de la primera edición de poesía medieval, de TOMás ANTONIO SÁNCHEZ (Colección de poesias castellanas anteriores al siglo XV), cuyo tomo IV, donde se publica por vez primera el Libro de buen amor, data de 1790. 
Samaniego sólo reconocía en su Prólogo la influencia lafontainiana en dos fábulas "y en alguna otra». Pero esta apreciación se queda excesivamente corta, o cuando menos, es suavizada por el autor, ya que las fábulas inspiradas en mayor o menor grado en La Fontaine superan la cincuentena.

El autor francés G. Germain, en su artículo «La Fontaine et les fabulistes espagnols» traza una estadística basada en los cinco primeros Libros, ya que la presencia francesa - según su criterio- no es tan acusada en la segunda parte de la obra. En dicho artículo, el autor estudia la influencia que pudo ejercer La Fontaine en la constitución de la fábula como género literario en el siglo XVIII español y en la evolución de dicho género que, evidentemente, menospreciaba ${ }^{9}$. A Samaniego le acusa de tener más ambiciones literarias de las que confiesa, y de otras muchas cosas. Tachando al fabulista de mal pintor de animales y de autor de paisajes convencionales, le concede, en cambio, un rasgo que le acerca a La Fontaine: su moral, de carácter «tibio», es decir, de naturaleza pragmática, que Germain encuentra útil para Samaniego, al poder así éste resguardarse tras el ejemplo de una obra francesa en caso de intervención eclesiástica. Según Germain, en fin:

L'indépendance esthétique, l'indépendance morale, tels sont donc les deux présents que La Fontaine apportait à la naissance de la fable espagnole...(Ibid. 322)

Pero, como ha quedado patente, la fábula en España no nace con Samaniego, ni gracias a la sola contribución de La Fontaine. Samaniego, junto con Iriarte, hizo florecer un género que sería muy prolífico en el siglo XIX.

Samaniego, como señala A. I. Sotelo, fue un representante genuino de su momento histórico, típico ilustrado, y sus $F a ́ b u l a s$ constituyen una vertiente de la «poesía ilustrada»; según este último autor: «La poesía en manos de Samaniego (...) se transforma en un instrumento para instruir, educar, deleitar o simplemente divertir...» (1997: 52). E. Palacios enumera los principios propios del espíritu del siglo contenidos en las fábulas en su obra Vida y obra de Samaniego (1975:211-213). Del mismo modo, Sotelo en su edición, al igual que Martínez Mata en la suya, destacan las ideas ilustradas que se aprecian en dichos textos $(1997: 56 ; 1998: 39)$.

9 Germain concluye con dureza: «Un enseignement ne vaut pas seulement par sa matière et par celui qui le donne, il vaut aussi et peut-être surtout par celui qui le reçoit. C'est ce qui ressort clairement de ces aventures de La Fontaine chez ses confrères espagnols. Il fut utile aux plus ouverts; les autres n'en retirèrent ni avantages, ni inconvénients. Il ne pouvait sauver de la mort ceux qui n'étaient pas nés pour vivre» (1932:329). 
Se ha atribuido a ambos fabulistas distintas cualidades; se ha tratado de establecer comparaciones —difíciles, por su diversidad—; Samaniego: descuidado, sencillo, espontáneo. Iriarte: elegante, gran versificador, correcto, creador...

La tumultuosa relación entre Samaniego e Iriarte es bien conocida; su admiración, no exenta de celos, sus ataques, reflejados en escritos de carácter panfletario. No me detendré en este género de anécdotas, no porque carezcan de interés, sino porque, ya reflejadas por numerosos autores, no van a ser repetidas aquí. Sólo pretendo hacerme eco de la importancia de los dos autores, coetáneos en este momento de la fábula dentro del ámbito de la lengua castellana.

Iriarte escribió setenta y seis fábulas literarias, nueve de las cuales se publicaron después de su muerte, ocurrida en fecha temprana. El calificativo de literarias obedecía a su voluntad de renovar la naturaleza de unas fábulas que perseguían la estética más que la moral y que a su vez eran completamente originales.

En cuanto a los rasgos del autor, se resumen en los siguientes puntos, siguiendo la caracterización ofrecida por E. Cotarelo en su obra Iriarte y su épo$c a$ : prolífico versificador, poseedor de un fluido manejo de la rima castellana, así como de un lenguaje castizo, caracterizado por su pureza y adornado con un tono jocoso, y a menudo satírico.

No me referiré a otras cualidades ya enumeradas, ni a los principios defendidos por Iriarte — deudor de la preceptiva horaciana—. Sí juzgo importante destacar su marcado espíritu crítico, que acercaba muchas de sus fábulas a la sátira. Iriarte dedicó gran parte de su tiempo a la polémica. De 1774 a 1778 dirigió a algunos de sus amigos Epístolas en verso en las que criticaba ciertos abusos de su tiempo, lo que hizo constar en una curiosa autobiografía escrita en tercera persona, procedente de un manuscrito presuntamente inédito: «Apuntaciones que un curioso pidió a don Tomás de Iriarte, acerca de su vida y estudios, escritos en treinta de julio de 1780» (Ms. de la Biblioteca Nacional de Madrid, n. ${ }^{\circ}$ 10.460), y recogida por $S$. de la Nuez en su edición de las $F a ́$ bulas literarias (1983:14).

A. Cioranescu se muestra contrario a la utilización de las fábulas por parte de Iriarte como un instrumento de lucha, calificando la composición de aquéllas de fría y de prosaica ${ }^{10}$. Pero el espíritu crítico se encontraba implícito en el siglo XVIII, y el mismo Iriarte hubo de padecerlo, siendo objeto, primero en su tiempo y después en nuestro siglo, de los más diversos juicios. Es más,

10 Según Juan Antonio Ríos, en La Poesía del siglo XVIII, acusar de prosaicas a las fábulas de Samaniego e Iriarte... «supone olvidar el objetivo que perseguían y, lo que es más importante, la búsqueda estética que suponen dentro de un género tan complejo omo otro cualquiera" (1992:138). 
como su hermano Bernardo, fue censurado por la Inquisicion, viéndose obligado a comparecer ante el Tribunal de Corte para abjurar de sus errores y ser absuelto ad cautelam en el transcurso de un autillo de fe secreto, según noticias de M. Defourneaux en Inquisición y censura de libros en la España del siglo XVIII (1973:212)".

En la citada edición de S. de la Nuez, que sigue como texto base la última edición corregida y revisada por Iriarte, de $1787^{12}$, de las Fábulas literarias, contenidas en el tomo I de la «Colección de obras en verso y en prosa de don Tomás de Iriarte» (imprenta de Benito Cano, 1787), figura una advertencia del editor, ya puesta al frente de la primera impresión de 1782, que dice así:

...ésta es la primera colección de fábulas enteramente originales que se ha publicado en castellano. (1983:65)

La originalidad de las fábulas de Iriarte queda fuera de toda duda, aunque no así la de su carácter literario. Alberto Navarro, en el Prólogo de su edición de las Poesías de Iriarte, señala:

No es el creador de la Fábula literaria, pero sí el primero y único que ha dejado una extensa colección de ellas $(1976: \mathrm{XVI})^{13}$

El mismo criterio es sostenido por F. Vézinet, quien, reconociendo el carácter de invención de Iriarte, así como la orientación renovadora de sus fábulas literarias, se hace eco de la existencia anterior del apólogo literario en Horacio, en Fedro, en La Fontaine y en Lessing. El autor francés, que encuentra en las fábulas reminiscencias de Boileau y su Poética, destaca el tono satírico de éstas; su sequedad y causticidad, próximas a Fedro, a pesar de lo cual afirma en su obra Molière, Florian et la Littérature espagnole:

...ce recueil n'est pas dépourvu de talent (1909:196).

G. Germain alude igualmente al recuerdo de Boileau, y se pregunta sobre la posibilidad de una influencia lafontainiana sobre Iriarte, a cuyos apologos niega toda intención estética:

"Samaniego tuvo igualmente problemas con la Inquisición, eludiendo el castigo gracias a sus influencias. Según el criterio de E. PALACIOS (1975:1 16), no parece cierta su reclusión en el convento de carmelitas de El Desierto, afirmada por otros autores.

12 Las primeras ediciones se publicaron en 1782 , y gozaron de un enorme éxito.

13 A. Navarro, que es consciente de la ausencia de estudios sobre la fábula en la literatura española, ofrece en dicho Prólogo (pp. XLI-XLIV) la trayectoria de la fábula en las letras españolas. 
...ne serait-ce pas l'étude de notre fabuliste qui aurait attiré l'attention d'Iriarte sur les possibilités d'un tel genre? $(1938: 313)^{14}$

Como Germain, P. Merimée cree en dicha influencia, negando a Iriarte la creación de un nuevo género, lo que opone al juicio de E. Cotarelo. Y también F. C. Sainz de Robles afirma en su Fabulario español:

Iriarte conoció la fábula clásica a través de La Fontaine (1964:14).

Las opiniones son, a veces, muy contradictorias. Daremos dos ejemplos de ello. Menéndez Pelayo, en su Historia de las ideas estéticas en España, declara con rotundidad el carácter de inventor del fabulista:

Iriarte fue inventor de un nuevo género de poesía didáctica: la Fábula literaria, antes de él no ensayada sistemáticamente en ninguna literatura. Escribió, pues, una serie de fábulas, más ingeniosas que dramáticas ni pintorescas (...), algunas de ellas magistrales (...) No procede Iriarte con el desinterés narrativo que en sus fábulas pone La Fontaine, y que le hace gran poeta en un género inferior... (1940:298)

Y en el extremo opuesto, las palabras de A. Cioranescu:

Después de La Fontaine, no hay más fabulistas (1959:3).

Es preciso, pues, actuar con una extrema moderación e intentar matizar dichas afirmaciones. Por un lado, el talante de algunos autores y críticos franceses es claramente partidista. En cuanto a Cioranescu, éste, en su artículo «Sobre Iriarte, La Fontaine y los fabulistas en general» - al que pertenece la cita anterior - se muestra abiertamente hostil al género - «el más aburrido de la literatura preceptiva», a su juicio-, al que llega a comparar con una vieja vecina que nos persiguiera con sus observaciones y consejos. No fundamenta debidamente su afirmación arriba citada, y de Iriarte salva sólo su universo.

Por otro lado, el fabulista debió de conocer muy bien los escritos de La Fontaine, y enriquecerse sin duda por su conocimiento ${ }^{15}$; no en vano fue un

${ }^{14}$ Germain dedica a lRIARTE escasamente una página de su estudio, anteriormente mencionado, en la que trata inútilmente de encontrar la influencia aludida, incluso acerca de la elección del género fabulístico, reconociendo la falta de pruebas al respecto.

15 De hecho, su fábula «El León y el Aguila» (XXVI) evoca ciertas reminiscencias de "La Chauve-Souris et les deux Belettes» (II. 5) -que La Fontaine toma de Esopo-, siempre manteniéndose en el terreno de lo literario. 
gran traductor, aunque durante un periodo de tiempo relativamente breve. Su actividad abarcaba desde Fedro, cuyas Fábulas escogidas tradujo, hasta Horacio, con una traducción en verso realizada en 1777 del Arte Poética, pasando por diversos autores franceses como Voltaire y Molière; llevó también a cabo la traducción de los cuatro primeros libros de La Eneida en romance heroico.

Apreciaba, pues, Iriarte la literatura francesa, aunque criticara a los afrancesados - él mismo fue acusado de galizante_-; admiraba su lengua, lo que no le impedía atacar los galicismos presentes en el idioma castellano.

Volviendo brevemente a las características más sobresalientes de Iriarte, no puedo dejar de mencionar su obsesión por la verdad y la claridad —que subraya J. Arce (1981:266)-, su concisión y agilidad, su ingenio, su pericia rítmica y métrica. Para J. A. Ríos, su aportación radica en la perfecta adecuación entre el género, el propósito perseguido y el tratamiento poético (ibid.:142). En la edición de las Fábulas literarias preparada por S. de la Nuez se incluye un índice de los tipos de metros utilizados en las Fábulas —desde los alejandrinos de catorce sílabas hasta el romancillo de cuatro sílabas- en número de cuarenta. Dicho número contribuye a dotar de gran variedad a la estructura de las fábulas, que Iriarte maneja como un consumado versificador. Sin embargo, numerosas voces han puesto en duda la validez de esta faceta del polémico autor.

M. Pelayo cuestiona la calidad poética del fabulista, no sin dejar a salvo su auténtico potencial literario. Según el autor, el interés de las fábulas de Iriarte no reside en las moralidades...

...sino en el primor y gracia de la versificación y del lenguaje, y en cierto risueño espíritu de invención y adaptación satírica, que fue la única musa de Iriarte, a la cual debe la envidiable y justa popularidad de muchos de sus versos. (1940:299)

Más duro es el criterio de F. Lázaro Carreter, que afirma en su obra Las ideas lingüísticas en España durante el siglo XVIII: "Iriarte fue un hombre de ciencia escasa y de ningún ímpetu poético» (1985:240). Nos parece más justo y ponderado el juicio de J. Arce: «Cierto es que, en su obra poética, no puede a veces negarse cierta insufrible ramplonería; pero, en otros casos, hay que saber apreciar, y muy seriamente, una concepción estética sometida a las limitaciones que su siglo impone» (ibid.:254)

Lo que resulta innegable es que la popularidad del fabulista fue grande, incluso excesiva - si hacemos caso a A. Navarro- para el valor real de sus apólogos. Éstos han sido incluidos en numerosos textos escolares, y hoy se pueden encontrar no pocos ejemplos en la literatura infantil. Según noticias de J. A. 
Ríos, «Las Fábulas literarias son la obra poética del setecientos español que más ediciones ha tenido en España e Hispanoamérica...» (ibid.:140).

No resta sino llamar la atención sobre la armonía de la composición iriartiana, en paralelo con su condición de músico. S. de la Nuez le define muy acertadamente en su Prólogo:

Iriarte (...) quiso restituir el equilibrio de la naturaleza y el arte, siendo éste el signo formal y expresivo que abarca la estructura interna de todas sus fábulas. (1983:37)

No me voy a detener más tiempo en ambos fabulistas del XVIII, de sobra conocidos, remitiendo a las ediciones incluidas en la Bibliografía. Concluiré con una nueva cita de A. I. Sotelo suficientemente clarificadora:

Las fábulas de Samaniego, y también las de Iriarte, suponen la renovación en su siglo de un género de muy amplia tradición, que encontró en la preocupación moral que impregnaba las ideas ilustradas un ambiente propicio para su desarrollo. Samaniego en España, como La Fontaine en Francia, supone una nueva etapa en la historia del género; la fábula reaparece de su mano y si el francés fijó el modelo de fábula moderna, el riojano lo importó a la Península; y este modelo continuará vigente en la amplia nómina de continuadores. (1997:57)

José Iglesias de la Casa (Arcadio), nacido, como Samaniego y Jovellanos, en la década de los 40 , murió en 1791 , no viendo publicadas en vida sus Poesías, que más tarde lo fueron en tres tomos, el tercero de los cuales contiene unos pocos apólogos. Joaquín Arce, en su libro La poesía del siglo ilustrado, muestra la influencia ejercida por Cadalso sobre el autor y sitúa la poesía de Iglesias en la línea tradicional de letrillas ágiles y humorísticas, destacando su sentido colorista, su predilección por los motivos florales y el tema rococó de los jardines.

Francisco Gregorio de Salas, cuyo año de nacimiento se ha fijado en torno a 1730 , murió en 1808 . En el tomo I de sus Poesías ${ }^{16}$ incluye, junto a algunos epigramas, madrigales y églogas, lo que él denomina materia heroica, literaria y sagrada, así como ocho fábulas de total originalidad. Otro texto suyo recoge una Colección de los Epígramas, y otras poesías críticas, satíricas y jocosas, que comprende poesías de su juventud, e igualmente trece fábulas, una de las cuales pertenece al género de la fábula política. Arce subraya la preferencia de Salas por el pintoresquismo popular, defendiendo al «simpático fraile», ignorado en las

's El tomo II incluye las Parábolas morales (Madrid, Imprenta de Villalpando, 1803). 
historias de la Literatura, de la atribución de prosaísmo: «... no se ha sabido valorar esa mirada limpia e ingenua con que contempla el campo, describiendo aspectos de la vida natural, dotados por su candor de un innegable halo de poesía» (ibid.:260).

Todavía en el siglo XVIII, recordaré también a Miguel García Asensio; me limitaré a citar a Bernardo M. ${ }^{a}$ de Calzada, como traductor de La Fontaine y de otros muchos autores ${ }^{17}$.

José Agustín Ibáñez de la Rentería, coetáneo y amigo de Samaniego, en la Introducción a sus Fábulas en verso castellano, reconocía su préstamo de La Fontaine y de Esopo, «descargando» su culpa mediante la alusión a los fabulistas que, como Fedro y el mismo La Fontaine, dieron nueva forma a argumentos griegos ya existentes. Su obra contiene dos volúmenes, con 115 fábulas el primero y 64 el segundo, cada uno de ellos con dos Libros. En ambos casos, el Libro II es original; en cuanto al Libro I, Ibáñez se inspira en La Fontaine en veintidós fábulas del primer Tomo y en dos del segundo.

Su obra no gozó de gran aceptación. Ya en el siguiente siglo, el fabulista M. A. Príncipe juzgaría sus fábulas carentes de ingenio; de hecho, este autor, reformador activo, fue más conocido por sus Discursos, y por su significación política de carácter liberal. Ibáñez de la Rentería, como buen representante de su siglo, aspiraba a «aprovechar y deleitar», expresando en la Advertencia del primer volumen su convicción en la utilidad de las fábulas para todas las edades.

\section{EL SIGLO XIX}

El siglo XIX es muy rico en fabulistas, que cultivan el género en sus vertientes más diversas. Hasta el momento se han mencionado sobre todo fábulas de contenido moral, y literario. Pues bien; en este siglo surge un abanico de fabulistas, cuya obra reviste además otra naturaleza, bien sea mitológica, política o social, y hasta militar, que viene a reflejar el momento historico en que aquéllos se hallaban inmersos.

Trataré de presentar a los fabulistas más sobresalientes de los que han sido encontrados, ya que la búsqueda ha sido con frecuencia ardua. Sainz de Robles se hace eco de dicha dificultad, cuando afirma, tras la Bibliografía elemental de la fábula incluida en su Fabulario español:

17 Para una información más exhaustiva acerca de las traducciones de Calzada, ver: «Un traductor del reinado de Carlos III: Bernardo MARIA DE CALZADA», de ANA Ma Freire (Investigación franco-española, $\mathrm{n}^{2} 2$. 1989; pp. 71-80). 
Más del 60 por 100 de estos libros de fábulas, no los posee la Biblioteca Nacional. (1964:21)

Se ha ordenado a la mayoría de los fabulistas según el año que consta en la edición utilizada, no resultando así la cronología todo lo exacta que sería de desear; de hecho, a veces se ha alterado el orden según el mayor o menor interés de los autores considerados, juzgando que lo que importa es la coherencia en exponer su obra o influencias.

Ramón Pisón y Vargas, fabulista denostado por M. A. Príncipe, es enteramente original - ésta será la corriente dominante en el presente siglo- En el Prólogo de sus Fábulas originales en verso castellano, el autor señala que la publicación de éstas, lejos de obedecer a ruegos de amigos o a encargos de Prócer - el fabulista fue ministro togado del Real y supremo Consejo de la Guerra-, se debe a su calidad...

...Y si disgustan al lector, que lo lleve con paciencia: ...que algo ganarás con Dios. $(1819: 3-4)^{18}$

Según R. Pisón, en fin, sus fábulas, en número de sesenta y ocho, son originales, si no en pensamientos, en todo lo demás.

Rafael José Crespo, catedrático de leyes en la Universidad literaria de Zaragoza, de gran cultura, sería considerado por M. A. Príncipe como un fabulista aceptable, con la salvedad, según palabras de este último, de que sus apólogos fueran refundidos y corregidos...

...pero tales como su autor los dio a luz, es imposible que satisfagan aun al menos descontentadizo. (1861:XV)

Como en los demás casos, he procurado —cuando ello ha sido posible-, aprovechar al máximo el Prólogo o Introducción situados al frente de las fábu-

${ }^{18}$ Fábulas... Dadas á luz por su sobrino D. Juan Bautista Iturralde de Pison y Vargas (Debe de ser este último el JuAN Pisón al que hacen referencia HaRTZenbusCh y S. DE Robles, como autor de unas Fábulas políticas y morales alabadas por NÚNEEZ DE ARCE). El autor hacía gala de una actitud realmente paciente, lo que demuestra al indicar en una leyenda situada al comienzo del libro, previa al Prólogo (p. 2):

A ninguno difama la censura en siendo general; y á quien le toca, que procure enmendarse, $y$ punto en boca. 
las por sus autores. En el caso de R. J. Crespo -oidor de la Audiencia de Aragón y consejero de S. M., según noticia de Sainz de Robles-, la presentación de sus Fábulas morales y literarias: "À Quien leyere», me ha sido de gran utilidad. En ella se excusa el autor:

Estos son mis primeros ensayos de poesía, obras del momento, y frutos de una edad demasiado temprana, y de unos estudios inmaturos; porque las hice muchos años ha, á excepcion de algunas pocas. (MDCCCXX:4)

C. García Gual, al contrario del riguroso juicio de Príncipe, incluye al fabulista, al que denomina «el horaciano aragonés», en su libro El zorro y el cuervo, presentándole como uno de los primeros representantes de la «fábula poética» y reivindicando - aun sin pretenderlo- su memoria. Según García Gual, el autor «Es (...) muy representativo en sus fábulas de la tendencia ilustrada y poética, donde es más importante el gracejo que la brevedad, el gusto por la invención y el ingenio antes que la moraleja, si bien no se renuncia al tópico lema de la utilidad moral del apólogo, especialmente dirigido a personas jóvenes». (1995:100)

G. Germain se hace eco del resentimiento de Crespo hacia La Fontaine por los versos «desmoralizadores» de los cuentos de éste, aludiendo a la única fábula del autor francés que le sirve de inspiración, «Le Jardinier et son seigneur». Efectivamente, R. J. Crespo rompe la línea de originalidad, lo que no oculta. Según el autor, hay algunas de sus fábulas que son originales; en cuanto a las que no lo son:

...lo es la manera de trazar y ejecutar sus planes. (MDCCCXX:5)

Crespo utiliza diversos metros, siguiendo el ejemplo de Iriarte, aunque huye de la tiranía de una rima difícil; y en cuanto a su estilo, procura que éste sea sencillo, popular y a la vez novedoso. Natural a su vez, el fabulista cita algunos autores de los que toma sus argumentos para sus 96 Fábulas morales y literarias: Ibáñez, Florian, La Fontaine... afirmando su intención de imitar a los mejores.

Ángel Casimiro de Govantes es el autor de Fábulas, cuentos y alegorias morales del doctor $d$..., obra que contiene un apartado dedicado a Fedro y otro a Esopo, y cuyas fábulas son de una longitud extremada, y algunas de ellas de gran rareza, como «El mono de un rimador». El fabulista, en nota (1) a su Prólogo y fábula I: «Juan y Juana y unos pasageros», da cuenta de la procedencia de esta última, que no es otra que un famoso cuento de El Conde Lucanor, en 
su versión publicada por Argote de Molina e impresa en Sevilla en 1575, y que según su criterio, serviría también de inspiración a La Fontaine:

La Fontaine en la fábula primera del libro $3^{\circ}$ intitulada: «Le Meûnier son fils et l'Âne», dió casi traducido al francés, y hermosamente adornado, el publicado por Argote de Molina. (1833:8)

Se trata del cuento II de la Primera parte, «Lo que sucedió a un honrado labrador con su hijo». En varias ediciones francesas consultadas de las fábulas de La Fontaine se dan otras posibles fuentes: las Mémoires de Racan sobre la vida de Malherbe, Huet, Faërne, Verdizotti, o bien que se tratara de una historia especialmente dedicada a su amigo Maucroix. A. C. de Govantes ha logrado introducir la duda: ¿acaso La Fontaine conoció la traducción francesa del Conde Lucanor, de M. de Puibusque?

Sainz de Robles selecciona seis grandes cultivadores de la fábula en verso en España; y, tras el Arcipreste, Samaniego e Iriarte, sitúa a Juan Eugenio Hartzenbusch, a Miguel Agustín Príncipe y a Ramón de Campoamor. Voy a ocuparme a continuación de estos tres grandes fabulistas del siglo XIX.

Las fábulas de Campoamor —en número de cincuenta y cuatro- se publicaron en 1842. Fueron éstas obra de juventud, más tarde rechazadas por el autor, y de hecho abąndonadas, ya que no escribió más fábulas tras dicha publicación. Según el juicio de Sainz de Robles, en su estilo es Campoamor más original que Hartzenbusch, aunque inferior a él en naturalidad y en inspiración poética. Su filosofía, un tanto vulgar, y sus moralejas, difícilmente deducibles. Pero E. DíezCanedo, que describe a Campoamor como aficionado a la filosofía y creyente en el progreso científico, aprecia su sencillez en la expresión y su búsqueda de la expresión directa —aunque, según su criterio, «se pasó de la medida»—: «Nada que no pueda decirse en prosa ha de entrar en el verso, según él, sea sólo el verso una manera de decir» (1965:12). M. Pelayo subraya su malicia e intención irónica.

Es interesante señalar los subtítulos explicativos del contenido, como por ejemplo, en la fábula XIII: «La carambola» (El chico, el mulo y el gato).

G. Germain identifica a la fábula trece de la que denomina «sección política» como una transformación de «Le loup et l'agneau». Se refiere sin duda a la fábula XIX: «Un daño destruye otro» (El dogo y los dos lobos), con distintos actores, una argumentación mucho más extensa y, que Campoamor podría haber tomado igualmente de Esopo o de Fedro. He aquí su moraleja: 
traban lid importuna
dos enemigos fuertes,
y no les dan ninguna,
por querer con afan darles dos muertes!

J. E. Hartzenbusch escribio fábulas desde 1824 hasta 1862 . Publicó alrededor de doscientas fábulas en dos colecciones, la primera de ellas, Fábulas puestas en verso castellano, en 1848, y la segunda, Cuentos y fábulas, en 1862 . El autor de la Nota Preliminar (firmada: F.S.R.) situada al frente de la edición de las Fábulas y Cuentos completos que hemos manejado, destaca su dominio de la fábula, según su criterio, más original e ingeniosa y de más correcta versificación que la de Iriarte y Samaniego, así como su dominio del idioma. Sainz de Robles afirma que ni siquiera La Fontaine le llego a aventajar en dichas cualidades. Ciertamente, su perfección, su erudición, su justa concisión, eran innegables.

Hartzenbusch no fue totalmente original, lo que él mismo reconoce en el Prólogo de la citada edición, en el que afirma haber traducido unas veces, imitado otras, e incluso haber refundido o desfigurado el original. Sus fuentes son bien distintas a las utilizadas comúnmente por otros fabulistas, tomando preferiblemente sus temas de autores alemanes, como G. K. Pfeffel, J. W. L. Gleim y sobre todo, G. E. Lessing. El escritor dedica en su Prólogo palabras elogiosas a «las excelentes fábulas» de su amigo don Ramón de Campoamor, y justifica muy pertinentemente su propio modo de actuar, que nos recuerda al de Ibáñez de la Rentería:

Si La Fontaine y Samaniego, sin subir a Fedro ni a Babrio, se valieron de lo que hallaron ya escrito, y no fueron rigurosamente fabulistas originales, ¿Ha de ser culpa en un moderno lo que fue digno de alabanza en sus predecesores? Parece que no. Aunque estas fábulas no sean originales, basta que sirvan de algo para que sea lícito publicarlas. (1963:26)

Llegamos a Miguel Agustín Príncipe, de algunas de cuyas críticas negativas ya hemos sido testigos, dirigidas a Ibáñez de la Rentería, a Ramón Pisón y Vargas, a R. J. Crespo; además de ellos, a L. Folgueras y a R. Valvidares, a M. F. Cidon é Iturralde, al Marqués de Casa-Cagigal, a J. Escoiquiz...

Mas este autor, doctor en Filosofía, abogado, catedrático de Literatura en Zaragoza, Bibliotecario de la Nacional, dedica su apreciación más positiva a

${ }^{19}$ Fábulas orijinales por d. RAMÓN DE CAMPOAMOR. Fábula XIX. Se trata de una bellísima edición, que merece la pena contemplar. 
otros muchos fabulistas. Admirador de La Fontaine y de Florian, ensalza a Samaniego, que dice ser más adecuado para niños; a Iriarte, más propio para adultos. Elogia a Campoamor y a Hartzenbusch, a Fernández Baeza, a Trueba, a Pravia, al Barón de Andilla, a C. de Beña, a C. de Govantes, a J. M. Tenorio...

Las Fábulas en verso castellano y en variedad de metros comprenden ciento cincuenta fábulas, distribuidas en seis Libros, $y$ van precedidas de un Prólogo que contiene la Historia de la Fábula de Esopo a nuestros días, y seguidas de un Arte métrica, en que se analiza la versificación castellana y se explican los tipos de metro de estas fábulas. Este último apartado aparece en forma de diálogo entre un joven aficionado a las Bellas Letras y el autor de las mismas fábulas.

Dichas fábulas son morales, excepto algunas literarias y políticas, según afirma Príncipe en su Prólogo, y «adaptables en su mayor parte a la comprension de los niños»...

...y si no, les ayudará su Maestro como hace con el Catecismo. De análoga manera debe ser ayudada la inteligencia infantil, tanto en lo que la Fábula tiene de literario, como respecto à su intención moral, destruyéndose así las objeciones que en su Emilio hace Rousseau al Apólogo en general, y en especial á los de La Fontaine. $(1861: \mathrm{XXI})$

Príncipe introduce elementos inanimados en sus fábulas. En su Prólogo muestra su intención de lograr un lenguaje claro y perspicuo, una versificación natural y fácil, unos caracteres verídicos, y una moral íntima, e ingeniosa. Justifica la aparición de la moraleja en primer lugar como un procedimiento excepcional, y en fin, aporta algunas muestras de originales -según el autor, excepto veinte o treinta fábulas que traduce o imita a sabiendas, son todas originales- utilizados para la composición de sus fábulas, a petición de algunos de sus amigos: a través de estos ejemplos se aprecian los procedimientos empleados por el fabulista. Los préstamos no pertenecen a La Fontaine en ninguno de los casos.

Una edición de Fábulas de Príncipe de nuestro siglo confirma su actualidad $^{20}$. Su ingenio queda demostrado en su fábula CVIII, contenida en el Libro $5^{2}$, y que reproducimos a modo de ejemplo:

${ }^{20}$ La edición está fechada en 1956. No indica de quién es la selección; sólo: Cubierta por: Carlos Freixas; ilustrado por: Emiloo Freixas. En la página 4 leemos: «...Da a conocer sus fábulas en Madrid en 1841; conservan su agilidad y valor literario y las moralejas no han perdido originalidad, sobre todo 'las que rozan los campos políticos de otrora'». 
«Traductio traductionis»

« $O h$, quantum, en un libro de latín,

Est in rebus inane!» Blas leyó;

Y como nada de ello comprendió,

Endosólo á un Barbero zarramplin.

Este se ví́ apurado, y dijo: «Oh Deus!

Oh maldito latin! oh mea meus!»

Mas luego gritó ufano: «ya salió!»

esta á Blasillo traducción le dío:

«Oh Dios, CUANTOS ENANOS HAY EN REUS!»

¿Traduccion nos anuncias literal

Por no dar de la libre en el error?

Pues perdona, querido Traductor:

Un dedo apuesto á que traduces mal.

Antonio de Trueba y Carlos de Pravia son los coautores de las setenta y dos Fábulas de la educación ( $1^{\mathrm{a}}$ ed. de 1850 ) que, según consta en la edición manejada (1879), fueron corregidas y notablemente aumentadas por el primero de sus autores, ya que C. de Pravia había fallecido en 1868. Antonio de Trueba cuenta en el Prólogo el proceso de gestación de dicha obra.

A continuación del Prólogo de esta segunda edición, en el que Trueba da cuenta de su labor de corrector de todas las fábulas, de la supresión de alguna de ellas y de la adjunción de catorce más - de la cincuenta y siete a la setenta pertenecen a su pluma-, aparece el Prólogo de la primera edición, redactado por los dos autores. Éstos exponen así su criterio:

...Samaniego, Iriarte, Rentería y otros comprendieron sin duda la conveniencia de una colección de fábulas capaces de ejercer en su patria la influencia que en Francia ejercían las de La Fontaine; pero sólo el primero tuvo bastante ingenio o bastante perseverancia para llenar una parte de aquel vacío. (1879:6)

A pesar de esta afirmación, los fabulistas juzgan que la moral de las fábulas de Samaniego es poco sencilla, o poco ortodoxa para un pueblo católico, y añaden que tampoco Campoamor ni Hartzenbusch lograron unas fábulas apropiadas para los niños. Aunque alaban las colecciones de Príncipe y de Raimundo de Miguel, los autores estiman que ningún fabulista español podría competir con La Fontaine. Ellos, por su parte, se declaran libres de cualquier ánimo de rivalidad o competitividad. 
A. de Trueba y C. de Pravia se inspiran en algunos autores alemanes, tomando también unas pocas fábulas de La Fontaine, lo que indican claramente entre paréntesis. Al final de cada fábula se indica igualmente la inicial de su autor.

Carlos de Pravia, que se dedicó más exclusivamente al periodismo, se ejercitó también en la novela y el teatro. En cuanto a Antonio de Trueba, fue un autor muy conocido en su tiempo, a pesar de los humildes orígenes de su vida literaria; también dedicado al periodismo, escribió más de veinte volúmenes, con un centenar de títulos.

Seguiré mencionando a otros autores que merecen aparecer en este repertorio por haber aportado su contribución - cada uno en su medida- al género. José Selgas y Carrasco, autor de una colección de poesías llamada La primavera, comparable a Hartzenbusch según el prologuista, Manuel Cañete, quien destaca el sentido metafísico de esta obra, en la que se representa sobre todo al mundo vegetal; la segunda edición contiene un apartado dedicado al Apólogo. Concepción Arenal, autora de unas Fábulas en verso originales, con fines pedag6gicos ${ }^{21}$, en número de cincuenta.

Pascual Fernández Baeza, considerado digno de mención por Sainz Robles, es el autor de una Colección de las Fábulas políticas concebidas con el propósito de formar el corazón de la infancia y de la juventud; según la intención confesada por el fabulista en el Prólogo, son morales para los niños de su familia; políticas, para recitarlas en el círculo de sus amigos.

Francisco Garcés de Marcilla, Barón de Andilla, en sus Fábulas, cuentos y epigramas morales ${ }^{22}$, se dirige al lector en un Prefacio en verso, resignándose a ser criticado. Le guía, dice, el deseo de «derramar útil semilla». Sus noventa y siete fábulas, también en verso, incluidas en el Libro primero, no denotan influencias.

José Joaquín Mora —individuo de número de la Real Academia-, en sus Poesías, que son fábulas en realidad: «La gata y los gatos» (en que la gata se llama Zapaquilda, en recuerdo a La Gatomaquia), «La zorra y el gato», «El milano y el palomo»..., parece igualmente original. Y también lo es Ramón Torres Muñoz de Luna, con su obra El álbum de mis hijos, de «inesperado» éxito, cuyo género no se atreve a calificar el autor, pero que, según lo describe en la Advertencia inicial, reúne las condiciones de la fábula: forma agradable, condensación de pensamiento e instrucción amena.

${ }^{21}$ Tras el título se indica entre paréntesis: obra aprobada para testo en escuelas de instrucción primaria.

${ }^{22}$ Existen otras ediciones, bajo el título: Fábulas y Cuentos Morales en variedad de metros, en los años $1856,1870-72,1878,1879$. 
Raimundo de Miguel es el autor de Fábulas morales escritas en variedad de metros. En el Prólogo de sus 150 apólogos, el fabulista, que acometió su elaboración cuando empezaba a perder la vista, afirma la originalidad de sus argumentos y manifiesta su aspiración de amenidad, cuidando la sencillez del estilo, la dicción pura y castiza y la versificación fluida y natural.

Felipe Jacinto Sala es un autor destacable. En sus ciento trece Fábulas religiosas y morales... ${ }^{23}$ se percibe, si acaso, la filiación de Samaniego o de Iriarte («La hormiga y la cucaracha»). Autor muy prolífico, escribió fábulas durante toda su vida. En el Prólogo incluido en sus Nuevas Fábulas - adornadas con bellas ilustraciones-, Carlos Frontaura augura un gran éxito al fabulista:

...Escribir buenas fábulas es de lo mas difícil que conozco en literatura, y lo prueba que son contados los autores que, en lo antiguo y en lo moderno, han sobresalido en este género. El Sr. Sala ha adquirido, con sus dos libros de fábulas, indisputable derecho á figurar como uno de los mejores entre esos pocos. (1886:X)

A causa de su carácter marcadamente moral, las fábulas de Sala aparecerían a menudo en textos escolares. Como ésta:

«La Malva» (Fábula LXIX)

Un pié atrevido

Pisa una Malva;

$Y$ ella que ignora

Lo que es venganza

Le aromatiza

Con su fragancia.

Las verdaderas

Almas cristianas

Son generosas

Como esta planta.

«La malva», así como «La violeta» y «La luz y las ranas» están recogidas en Lecturas graduadas (Libro primero, Zaragoza, Luis Vives, 1953), del que

${ }^{23}$...en verso castellano y en variedad de metros. Estas fábulas fueron premiadas por la Sociedad económica barcelonesa de amigos del país. El director, así como el socio secretario primero de dicha Sociedad les atribuyen las siguientes cualidades en la pesentación que las precede: naturalidad, versificación fácil, lenguaje correcto. 
forman parte otras muchas fábulas —en doscientas páginas, se encuentran cinco fábulas de Esopo, cinco de Samaniego, dos de Iriarte, dos de Hartzenbusch, dos de A. de Trueba, una de Manuel del Palacio, una de Campoamor, una de Cayetano Fernández, una de Florian, una de Baeza, una de Príncipe, y dos de Schmid-, lo que ocurre igualmente en otros libros escolares. Ello es una muestra de la gran profusión, así como del carácter pedagógico y moralizante de la fábula, tanto en la segunda mitad del siglo XIX como en la primera mitad - y a veces más allá- del siglo XX.

Pablo de Jérica, que publicó sus treinta y cinco fábulas conjuntamente con otras obras en 1831, fue a su vez traducido al francés en 1870 por Hippolyte Topin.

Procedemos, pues, a la inversa en esta ocasion. H. Topin hace preceder sus Fables de Jerica «traduites pour la lère fois de l'espagnol en vers français» de una introducción sobre el apólogo en España, y traduce las fábulas que considera más importantes: «Le rat dans le fromage», «Le rossignol», «Le royaume des brutes"..., que ascienden a veintitrés, y como apéndice a éstas, traduce igualmente algunas fábulas de otros autores, como Príncipe, Iriarte, y Campoamor.

Un caso realmente curioso, al que otorgo un carácter anecdótico, es el de Fernando Martín Redondo ${ }^{24}$. El mismo autor explica el enfoque de sus fábulas en la Introducción -que firma como F. M. D’Ornedo-, a través de una supuesta carta redactada por los animales que deberían protagonizar aquéllas, firmada por «Gongorila de Chimpanzé»:

«...estamos resueltos á no consentir que los grajos se atavíen con las plumas del pavo real...» (p. 2)

«...En cuanto á las fábulas morales de que tanto se enorgullecen ustedes, sólo diré que casi todas ellas han sido escritas por nosotros y para nosotros» (pp. 4 y 5 )

«...le remito una colección de fábulas originales nuestras y que hace tiempo plagí́ y publicó en España un Sr. Samaniego, á quien aquí nadie conoce...» (p. 5)

La originalidad de estas fábulas a la inversa, que no buscan ofender «la animalidad racional», consiste, pues, en que actúan en ellas los seres humanos. Como en el siguiente ejemplo:

${ }^{24}$ La edición de sus Fábulas cuasi morales escritas por animales y arregladas en verso cuasi castellano por... aparece sin año, por lo que la he situado aquí, disponiendo, como único dato, de la fecha de edición de otra de sus obras: Un cazador predestinado (Madrid, Imprenta de la Biblioteca de Instrucción y Recreo, tomo 25. Madrid, 1871). 
XIII. «Ramona y el Busto» (LA ZORRA Y EL BUSTO, de Samaniego)

Dijo Ramona al busto

De don Ruperto:

«Fuiste en vida de mármol,

Ahora de yeso.

Como tú hay muchos

Que parecen de carne

Y son de estuco".

Vicente Regúlez y Bravo es autor de sesenta y tres Fábulas distribuidas en dos Libros $\rightarrow$ que no denotan influencias-, dirigidas a los padres y profesores, y cuyo objetivo es, según indica en la dedicatoria, servir de utilidad, instrucción y recreo para los niños.

Las fábulas de Teodoro Guerrero, contenidas en la segunda parte de su obra Lecciones del mundo, son casi todas originales. En la presentación, a modo de Prólogo, el autor expone la opinión vertida por algunos literatos en la prensa en torno a su obra. "Esto no es un prólogo escrito con una pluma; es un prólogo cortado con una tijera», exclama con ironía (1871:8). Hay que señalar que todas las críticas son positivas: «apólogos oportunos» (Joaquín M. de Alba); «unción religiosa y moral purísima» (Gertrudis G. de Avellaneda). José Fernández Espino llega a situarle al lado de Príncipe y de Hartzenbusch, juzgándole digno sucesor de Iriarte y Samaniego, y más original que todos ellos... Pero no hay que olvidar que en una de sus fábulas, la que hace el número $\mathrm{XX}$, «La carga ajena», el mismo escritor indica: «Imitación del francés», y alguna otra recuerda mucho a Iriarte («La pluma y la espada»).

T. Guerrero es también autor de un curioso libro, Fábulas en acción, que pretende ser un ensayo en el género dramático, orientado a adiestrar a los adolescentes en la lectura del diálogo en verso, y que contiene siete fábulas para ser desarrolladas - una de ellas, «El dinero y la hermosura», en tres cuadros-

La lista de cultivadores del género es interminable. Se encuentran en ella Ventura Ruiz Aguilera, y su Libro de las sátiras, conteniendo originales y larguísimas fábulas y moralejas entremezcladas con otros epigramas, poesías y sátiras. Alfonso Enrique Ollero, y sus Fábulas morales..., dedicadas a un público infantil y juvenil. José Doncel y Ordaz - aquí nombrado especialmente con objeto de contribuir a divulgar su nombre para la posteridad-, y sus Fábulas en verso castellano y en variedad de metros ${ }^{25}$, así como su segunda edición, deno-

${ }^{25}$ El autor indica en la Nota preliminar (p. VI): «...Si hubieran nacido en él (en su siglo) Pilpay, Esopo 6 Locmiano, Fedro 6 Gay, Lafontaine 6 Florian, Iriarte 6 Samaniego, tal vez no conociéramos hoy sus nombres, como la posteridad no ha de conocer el mío probablemente.» 
minada Fábulas morales, satíricas y filosóficas -de carácter satírico políticosocial y con algunas reminiscencias de fabulistas españoles (Campoamor), y alusiones a los mismos (Samaniego)-, cuyo prologuista, Luis María F. de Valdelorenzana, le juzga merecedor de un lugar distinguido en la literatura española.

Timoteo Domingo Palacio, y su Mosaico Literario. Coplas y versos, dedicado «a Miguel Cervántes Saavedra», que contiene Sonetos, Letrillas, Epigramas, y algunas fábulas. Manuel del Palacio, y su Fruta verde. Misceláneas en verso y en prosa, con una parte de cuentos y fábulas entre las que destacamos «La oveja y el lobo», y su moraleja:

\author{
Niñas, por Dios os pido \\ Que no déis esta fábula al olvido; \\ El amante más bobo \\ Cuando halla la ocasión se vuelve lobo.
}

José Estremera, y sus Fábulas. Sus Fábulas y Cuentos contienen cincuenta y siete fábulas, en varias de las cuales se insiste reiteradamente en la laboriosidad de la hormiga. Antonia Díaz de Lamarque y sus Aves y Flores. -Fábulas morales, cuya novedad, dulzura y sensibilidad femeninas son muy alabadas por el prologuista, Jose M. ${ }^{a}$ Asensio y Toledo, quien, defendiendo la oportunidad del género de la fábula en todos los tiempos, ensalza a Iriarte, y a los fabulistas de la escuela sevillana: Fdez. Baeza, M. A. Príncipe, R. de Miguel, Campoamor, Hartzenbusch.

P. Andrés Codoñer, y su obra El amante de los maestros, colección de fábulas en verso que comprende un Libro dedicado a los niños y los cuatro restantes a los Maestros, y cuyas fábulas, ricas en personajes animales, son más que aceptables. Su fábula «La liebre y la tortuga» ofrece la siguiente moraleja:
Si en algo fueres dotado
Más que otro no pienses ser;
Que es fácil te puedas ver
Del más humilde humillado.

Nicolás Pérez Jiménez, y sus Cien Fábulas, sencillas, persuasivas y enteramente originales, según el autor del Prólogo, Víctor Balaguer. (Pero «La encina y la mimbrera», «La urraca y la hormiga», ¿no emanan un aire ligeramente esópico?). Morales, filosóficas y literarias, estas fábulas abundan en protagonistas del mundo vegetal.

Manuel Ossorio y Bemard se sitúa a finales del siglo XIX, lo que se deduce de las fechas de edición de sus numerosas obras: 1866, 1871, 1873, 1876, 
$1879,1891,1896,1903 \ldots$ (el fabulista murió en 1904). En la presentación de su obra Ensayos poéticos, el autor alude a «su corta edad».

No debe inducir a confusión, pues, la fecha de edición de las Obras escogidas de Manuel Ossorio (1928). En el Tomo IV, al que titula: «Literatura para la infancia», dedica a sus tres hijos, y por extensión a todos los niños, una serie de poemas infantiles de tono moralizante que, conjuntamente con sus otros contenidos (Moral infantil, Album infantil. Cartas a un niño sobre Economía Política. Gente Menuda), tuvo una gran aceptación, declarándose libro de texto. El autor destaca la utilidad de la Fábula - para mostrar los vicios y males de la sociedad-, en sus poemas, algunos de los cuales son apólogos de tinte eś́pico. Destacamos aquí la moraleja de su fábula: «El niño y el maestro de escuela», en la que también se aprecia la huella de La Fontaine:

Que hay mil pedantes, cosa es evidente;

que hay quien tranquilamente

morir vería a toda su ascendencia

por lucir en el duelo su elocuencia,

no lo dudéis, porque lo mismo encaja

un discurso en la cuna o la mortaja.

«Razón te sobra en tu oratorio arranque,

"pedagogo, mas ve que no soy rana:

"sácame lo primero del estanque

"y di después cuanto te dé la gana.» (1928:29)

Para poner fin a este XIX tan floreciente, mencionaré a algunos de los fabulistas de díficil localización: Cayetano Fernández, autor de Fábulas Ascéticas, Ramón Valvidares y Cristóbal de Beña, cultivadores de la fábula política, el Marqués de Casa-Cagigal, cultivador de la fábula militar, Luis Folgueras, José Manuel Tenorio...

\section{El Siglo XX}

A comienzos del siglo XX, se observa un descenso en el número de fabulistas; o bien las fábulas de dichos autores constituyen una pequeña parte de una más amplia producción literaria. La calidad, por lo general, desciende igualmente. Daremos algunos ejemplos de ello.

En determinados casos, más que de fábulas, se trata de ripios más o menos ingeniosos, como ocurre en la obra de Carlos Cano, Fruta del tiempo -Poesías festivas-, que contiene un prólogo de Manuel del Palacio e inclu- 
ye «Fábulas» ${ }^{26}$, y «Fábulas Morales», del mismo tono, sobre máximas de «El consejero de la infançia». José Rodao designa directamente a su obra: Ripios con moraleja. Fabulillas; eso sí, originales. Igualmente ripios, y de ínfima calidad, son las autodenominadas fábulas de Fermín Sacristán: De mi banasta.

J. Rodríguez Mateo es el autor de Fábulas, en número de noventa, que no se distribuyen en Libros, y cuyo contenido es de naturaleza social - según señala el autor de su presentación, José $\mathbf{M}^{\mathbf{a}}$ Lozano-, y su originalidad mayor que la de otros fabulistas...:

...Nuestro autor, en sus fábulas, ha observado más e imitado menos que los otros, desde Pelpay a Juan Ruiz, desde Esopo a Samaniego...(1921:6)

Ciertamente, Rodríguez Mateo no denota influencias. Quizá su fábula «La Corregüela y el Tomillo» recuerda a «La Enredadera y la Violeta», de Nicolás Pérez Jiménez, mencionado entre los fabulistas de los últimos años del siglo XIX. Pero es arriesgado enjuiciar los contenidos de las fábulas y sus correspondencias con determinadas ideas, que pueden responder a otras influencias ya que, en cualquier caso, se trata de una consideración muy subjetiva.

Ramón de Basterra es un autor digno de mención en cuanto a su intento de modernizar la fábula mediante la transformación de los personajes tradicionales en máquinas que aleccionan al hombre, procedimiento también seguido por Juan José Nieto en su Fabulario Boreal.

Basterra dedica su composición poética «épicoalegórica» - como la califica Díez-Canedo-Vírulo 'Mediodia' ${ }^{27}$ a sus «tres amados maestros»: Ramiro de Maeztu, José Ortega y Gasset y Eugenio d’Ors. En su poesía: «Nuevo fabulario» (XII) expone su novedoso punto de vista:

...Se cerraron las fábulas a base

Del material del día quinto

${ }^{26}$ Damos un ejemplo de éstas:

De amor en un exceso

Una gata á su novio le dió un beso,

Y el padre de la tal, que era muy bruto,

Mató á los dos y no se puso luto.

iAdmiren los mortales

Cómo aprecian su honor los animales!

27 Vírulo es un personaje al que el autor compara con Hércules y con Pegaso. Existe una primera parte: Virulo 'Mocedades', de 1924. 
Quedan abiertas otras. Escuchad a las máquinas.

La gran sabiduría está en las máquinas.

Escuchad su lección de ritmo.

Calla doña raposa, don leớn, don caballo.

Avanza doña grúa, don cilindro, don émbolo.

Los títulos de sus «Nuevas fábulas», contenidas en la parte XIV de la citada obra, son una buena muestra de su original concepción: II. El buen camión; III. El avión y el molino; IV. El motor obscuro... En Estudios de poesía española contemporánea se recoge un artículo de E. Díez-Canedo (publicado originariamente en El Sol el 30-VIII-1928), dedicado a «La obra poética de Ramón de Basterra", en el que el crítico subraya su ímpetu poético y la concepción modernizadora de las «Nuevas Fábulas», en las que se enlazan lirismo y humor (1965:167). Basterra muestra igualmente su originalidad en una poesía redactada al modo tipográfico de Apollinaire, con ocasión de la aparición de la revista «Pyrenaica».

En 1958 se publicaría la Obra poética de Ramón de Basterra, incluyendo su fabulario.

Josefa Pardo de Figueroa escribio Solaces poéticos, que el P. Alberto Risco, en su prólogo-biografía, presentaba como un ramo de flores. La primera de sus producciones aparece bajo el nombre de: «Muestrario de fábulas fabulosas» (Sevilla, LXXVI), apadrinado y publicado por el Dr. Thebussen -éste, de famoso seudónimo, era hermano de Josefa Pardo, a su vez Marquesa de Pardo de Figueroa-, y contiene en su presentación la Aprobación de J.E. Hartzenbusch:

\author{
Libro ameno: \\ Poco y bueno. \\ No conozco la obra, \\ Pero adivino \\ Todo lo que ella vale, \\ Por el padrino. \\ La Aprobación de larga \\ No se me tache; \\ Hasta mi firma abrevio: J.E.H.
}

Su segunda colección, «Opiniones» y la tercera, «Fábulas no coleccionadas», al igual que la primera de ellas, tienen como denominador común su innegable originalidad, así como las constantes moralinas de esta piadosa marquesa, cuya inspiración nació, según el P. Alberto Risco, del patriotismo y de la caridad. 
Cesáreo de Miangolarra, que critica en el Prólogo a las nuevas tendencias, incluye algunas fábulas en sus Quejidos de mi salterio — El mochuelo y el cuco», «La gallina y el billete», «Los dos jilgueros»...-, compuestos por otros romances y doloras de carácter religioso, cuyos versos son atribuidos por el autor a la escuela antigua. Antonio Ríos, en la misma línea, critica a los «innovadores del arte», y en sus poesías Flores Marchitas inserta algunos apólogos: «Rosa y capullo», «La araña y la fregona», «La rana y sus hijos»... francamente ilegibles.

Avanzando en el tiempo, citaré a Federico Torres, y su libro Oid niñas, diseñado para servir de texto en las escuelas de Enseñanza Primaria, y que reúne canciones, historietas y fabulillas que mezclan prosa y verso, algunas de las cuales, como «La tortuga y el conejo» comienzan por: «Érase que se era...».

El carácter escolar de los textos encontrados es una constante. De hecho, las ediciones infantiles se habrían de continuar, proliferando, en los años 50 y ya bien entrado el siglo XX en el que, por otra parte, la fábula como género didáctico, moral o satírico aislado, no conoce una gran aceptación, no siendo en las mencionadas ediciones que son, casi siempre, adaptaciones a modo de cuentecillos dirigidos a los niños.

Hay que reconocer que dichas ediciones infantiles se han visto siempre coronadas por el éxito, debido, en gran medida, al destinatario al que se dirigen. Mas, según mi opinión, los fabulistas como tales han terminado. Pero no así los cultivadores ocasionales de la fábula: el matiz es muy importante. De hecho, si estudiáramos a fondo la obra de los autores españoles de este siglo, incluso la de nuestros contemporáneos, comprobaríamos que algunos de ellos han «acudido» a la fábula en algún momento de su trayectoria literaria, siguiendo una especial tentación nunca esperada, según parámetros de actualidad. Ofreceremos algunos ejemplos de ello.

Rafael Alberti dedica una fábula a Leonardo de Vinci en un libro que recoge las Fábulas y Leyendas de este último, traducidas por $\mathrm{M}^{\mathrm{a}}$ Teresa León, conjuntamente con el mismo Alberti.

Bruno Nardini, intérprete y transcriptor de dichas Fábulas y Leyendas, en la Presentación de éstas, a la que titula: «Leonardo narrador», pone de relieve las dotes de Leonardo como fabulador a veces improvisado, así como su riqueza de invención, que cautivaban a su auditorio...

...las fábulas de Leonardo, casi dos siglos antes que las de La Fontaine, se enlazaban espiritualmente a las fuentes de Esopo y de Fedro, de Plinio y de los «bestiarios» medievales. ${ }^{28}$

28 Fábulas y Leyendas de LeONARDo DE VINCI (1973). Ilustraciones de AdRIANA SAviozzI MAZZA. Barcelona, ediciones Nauta, S.A.; p. 7. 
El personaje protagonista de dichas fábulas, de carácter moral, que se transmitían por tradición oral a través de las cortes y también de las plazas de Italia y Francia, era la naturaleza. El hombre, el elemento negativo que podía destruirla. Todos estos datos y otros muchos más acerca de Leonardo son referidos y documentados por B. Nardini en una hermosa edición, en la que brilla de un modo especial la aportación de $\mathrm{R}$. Alberti. He aquí algunos de los versos de «La fábula de Leonardo»:

Por prados y colinas camina un bello anciano.

Se sienta junto al río, sigue hacia el mar, midiendo sus pasos en la arena. Sus ojos son dos lentes fijas que agrandan todo (...)

-Buenos días, señorle canta la calandria.

- Soy la higuera-Mis frutos son la envidia del olmo.

- Ten piedad de la parra, vencida por ingenua.

-Duélete de la ostra, víctima del cangrejo, por mirar a la luna.

- Soy el ratón, buen postre para la comadreja, aunque ignore que al punto va a comersela el gato. - Mira el grano de trigo trasportado en la boca de la crédula hormiga.

-Buenas noches - Yo soy

la llama en que se quema la loca mariposa (...)

- ¿Y tú, dinos, y tú?

—Yo soy, yo soy... Miradme.

¿Acaso no me veis?

Mi vuelo se remonta más alto que el del águila. Yo soy el hombre-pajaro. El primero que anhela ir al sol y a la luna. 
El pájaro mecánico, hoy asombro del mundo.

¿Queréis saber mi nombre?

Me llamo Leonardo.

Dijo así... Pero todos, dudando, sonrieron.

$Y$ la cola de un burro

le dio un golpe en la frente, creyendo era un mosquito.

Rafael Alberti Roma, 1973

Por su parte, el escritor Bernardo Artxaga enfoca su libro Dos Hermanos (Madrid, Ollero \& Ramos, editores, 1995. Novelas ejemplares) como una fábula, en la que personajes animados no humanos y hasta inanimados: un pájaro, seis ardillas, una estrella, una serpiente y una oca, obedeciendo a una voz interior, piensan y toman decisiones, participando activamente en la narración —en la que intervienen animados humanos-, tomando a su cargo simétricamente (la bondad y la maldad, el juicio y la sinrazón se distribuyen paralelos entre animales y humanos del mismo carácter) las vidas de cada uno de estos últimos. La fábula se resuelve conjugando la crueldad de la naturaleza y la transmutación alegórica liberadora de los animados humanos en no humanos.

Citaremos, por fin, al poeta Ángel González, cuya particular versión del apólogo en nuestro siglo se puede apreciar en los siguientes versos, pertenecientes al volumen Palabra sobre palabra (Barcelona, Seix Barral, 1994, p. 153):

(...)Ya nuestra sociedad está madura, ya el hombre dejo atrás la adolescencia y en su vejez occidental bien puede servir de ejemplo al perro para que el perro sea más perro, y el zorro más traidor, y el león más feroz y sanguinario, y el asno como dicen que es el asno, y el buey más inhibido y menos toro.

A toda bestia que pretenda perfeccionarse como tal

con fines belicistas o pacíficos, con miras financieras o teologicas, 
o por amor al arte simplemente-

no cesaré de darle este consejo:

que observe al homo sapiens, y que aprenda.

\section{CONCLUSIONES}

El objetivo de este trabajo está cumplido, si se considera su carácter de visión de conjunto, que permite apreciar cómo el género de la fábula se va adaptando según los rasgos que definen a cada siglo: su gran adecuación al movimiento ilustrado, y la posterior pérdida de su carácter utilitario, que entraña el descenso de su actualidad. En cuanto a los fabulistas, éstos no dedican su escritura exclusivamente a las fábulas, que conviven a menudo con otras obras, diversificando también la inspiración, de modo que a veces unas fábulas originales se mezclan con otras que no lo son, y que pueden proceder de distintas fuentes.

Tras el auge del siglo XVIII, en el siglo XIX las modalidades de las fábulas se diversifican, $y$ numerosos fabulistas se distinguen por su originalidad. Predomina la intención moralizadora y didactizante, lo que se pone de manifiesto en la presencia frecuente de la fábula en publicaciones escolares. Dichos caracteres, moral y pedagógico, se mantendrán aún a principios de nuestro siglo, a lo largo del cual, sin embargo, descenderá el número de fabulistas hasta desaparecer, así como el interés por el género, que quedará relegado a adaptaciones de carácter infantil, que - por otra parte - no han dejado de editarse y reeditarse regularmente, y no sólo en castellano, sino en otras lenguas de la península.

\section{REFERENCIAS BIBLIOGRÁFICAS}

\section{Los fabulistas españoles}

ARENAL, C. (1854): Fábulas en verso originales por... (obra aprobada para testo en escuelas de instrucción primaria). $2^{\mathrm{a}}$ ed. Madrid, Imprenta de $\mathrm{H}$. Reneses.

Basterra, R. (1926): Vírulo 'Mediodía' . Madrid, ed. de la Gaceta Literaria, Biblioteca Ibérica.

Basterra, R. (1958): Obra poética de... Publicaciones de la Junta de Cultura de Vizcaya, Bilbao.

CAMPOAMOR, R. (1842): Fabulas orijinales por... Madrid, Establecimiento tipografico, c/ del Sordo $\mathrm{n}^{2} 11$. 
Cano, C. (1902): Fruta del tiempo -Poesías festivas-. 2ta ed. aumentada. Con un prólogo de Manuel del Palacio. Madrid, Librería de Fernando Fé.

CODOÑER, P. A. (1894): El amante de los maestros. Colección de fábulas en verso castellano. 5 Libros. Valencia, Imprenta de Emilio Pascual.

CRESPO, R. J.: Fábulas morales y literarias. Zaragoza, MDCCCXX, en la imprenta de Luis Cueto.

DIAZ DE LAmARQue, A. (1890): Aves y Flores. Fábulas morales. Con un prólogo del Excmo. Sr. D. José $\mathbf{M}^{\mathrm{a}}$ Asensio y Toledo. Ed. ilustrada por D. Francisco Blanch. Barcelona, Pons y $\mathrm{C}^{\mathrm{a}}$, Editores católicos.

Domingo Palacio, T. (1880): Mosáico Literario. Coplas y versos. Madrid, Establecimiento tipográfico de Segundo Martínez.

DONCEL Y ORDAZ, J. (1877): Fábulas en verso castellano y en variedad de metros. $1^{\text {a }}$

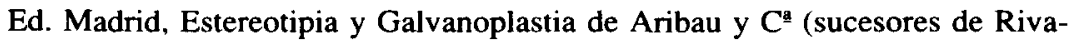
deneyra).

DONCEL Y ORDAZ, J. (1895): Fábulas morales, satíricas y filosóficas, precedidas de un prólogo del Excmo. Sr. D. Luis María F. de Valdelorenzana. 2ª ed. Badajoz, Imprenta, Litografía y Encuadernación de Uceda Hermanos.

Estremera, J. (s/a): Fábulas. Barcelona. Ed. Librería Española, Rambla del Centro $\mathrm{n}^{\mathrm{Q}} 20$.

Estremera, J. (1890): Fábulas y Cuentos. Madrid, R. Velasco, Impresor, Rubio, 20.

FERnÁNDEZ BaEZA, P. (1852): Colección de las Fábulas políticas. Madrid, Imprenta a cargo de $\mathrm{C}$. González.

FERNÁNDEZ BAEZA, P. (1858): Nueva colección de las Fábulas políticas. $2^{\mathbf{2}}$ ed. aumentada. Madrid, Imp. de M. Campo-Redondo-Huertas.

GaRCÉS DE MARCILla, F. (Barón de Andilla) (1853): Fábulas, cuentos y epigramas morales, dedicados a S. A. R. La Serma. Princesa de Asturias. Madrid, Imprenta y Estereotipia de M. Rivadeneyra.

Govantes, A. C. de (1833): Fábulas, cuentos y alegorías morales del doctor d... Madrid, Imprenta de D. Eusebio Aguado.

Guerrero, T. (1871): Lecciones del mundo. Páginas de la infancia. $6^{\mathrm{a}}$ ed. (las 5 anteriores se editaron en Cuba). Madrid, Imprenta de T. Fortanet.

Guerrero, T. (1876): Lecciones del mundo. Páginas morales en verso, $7^{\mathrm{a}}$ ed. aumentada. Madrid, Imprenta y fundición de Manuel Tello.

Guerrero, T. (1877): Fábulas en acción. Cuadritos dramáticos en verso. Madrid, Imprenta y Fundicion de $M$. Tello.

HaRTZENBUSCH, J. E. (1963): Fábulas y Cuentos completos. Madrid, Aguilar.

IBÁÑEZ DE LA RENTERfA, J. A.: Fábulas en verso castellano. Con licencia en la Imprenta de Aznar, Madrid, MDCCLXXXIX. $2^{\underline{a}}$ vol., con licencia en la Imprenta de Villalpando, MDCCXCVII.

Iglesias DE LA CASA, J. (1848): Poesías. $1^{\mathrm{a}}$ ed. 1840. Madrid, Imprenta de M. R. y Fonseca. 
IRIARTE, T. de (1976): Poesías. $3^{\frac{a}{2}}$ ed. Edición, Prólogo y notas de Alberto Navarro González. Madrid, Espasa-Calpe, Clásicos Castellanos, 136.

IRIARTE, T. de (1983): Fábulas literarias. Ed. preparada por Sebastián de la Nuez. Madrid, Editora Nacional. Biblioteca de la Literatura y el pensamiento hispánicos.

JÉrICA, P. de (1870): Fables de..., traduites pour la lère fois de l'espagnol en vers français par Hippolyte Topin. Livourne, Imprimerie de François Vigo.

Juan Manuel, Infante de Castilla (1991): El Conde Lucanor. Versión española mo-

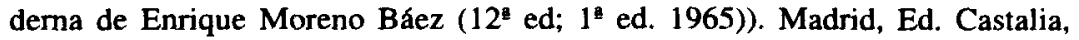
«Odres nuevos».

Llull, R. (1980): Llibre de meravelles. A cura de Marina Gustà. Pròleg de Joaquim Molas. Barcelona, edicions 62, s/a. Les millors obres de la literatura catalana, 36.

LLull, R. (1985): Llibre de les bèsties. Estudis introductoris de Jordi Rubio i Armand Llinarès. Barcelona, edicions 62 s/a. El Garbell, 17.

MARTIN ReDONDO, F. (s/a.): Fabulas cuasi morales escritas por animales y arregladas en verso cuasi castellano por... Madrid, Libreria editorial De Bailly-Bailliere É Hijos.

Miangolarra, C. de (1929): Quejidos de mi salterio. Poesías escogidas. $1^{2}$ ed. Madrid, Bruno del Amo, editor.

Miguel, R. de (1874): Fábulas Morales escritas en variedad de metros. $2^{\mathbf{a}}$ ed. Madrid, Agustín Jubera. Existe una $3^{3}$ ed. económica revisada y corregida por su autor para uso de las escuelas de instrucción primaria: Madrid, Sáenz de Jubera hermanos, ed. 10-Campomanes-10, 1890.

Mora, J. J. (1853): Poesías. Madrid, Calle de Sta Teresa $n^{2} 8$. Paris, Rue de Provence $\mathrm{n}^{2} 12$. Existe una edición de 1836.

Ollero, A. E. (1878): Fábulas Morales divididas en tres secciones especiales para niños, niñas y jóvenes adolescentes, precedidas de una carta del gran poeta lírico D. Antonio Fernández Grilo. $1^{a}$ ed. Madrid, M. Romero, impresor.

Ossorio y Bernard, M. (1859): Ensayos poéticos. Madrid, Imprenta de D. Félix Ochoa de Alda.

Ossorio y Bernard, M. (1928): Obras escogidas. Madrid, Imprenta de Juan Pueyo. PalaCio, M. del (1881): Fruta verde. Misceláneas en verso y en prosa. Sevilla, Francisco Alvarez y Ca, Impresores y Editores. Madrid, A. Alvarez Aranda, Admón. Universal.

Pardo de Figueroa, J. (1929): Solaces poéticos. Colección de versos reunidos e impresos como recuerdo íntimo por sus hijos, con un prólogo-biografía del P. Alberto Risco, S. J. Madrid, Talleres Voluntad.

Pedro Alfonso (1980): Disciplina Clericalis. Edición y traducción del texto latino de Ángel González Palencia, Madrid-Granada, C.S.I.C.

Pérez Jiménez, N. (1898): Cien Fábulas. Con un prólogo del Excmo. Sr. D. Víctor Balaguer. Barcelona, Establecimiento Tipolitográfico editorial de Ramón Molinas. 
PISÓN Y VARGAS, R. (1819): Fábulas originales en verso castellano. Dadas á luz por su sobrino D. Juan Bautista Iturralde de Pison y Vargas. Madrid, por Ibarra, impresor de Camara de $S$. $M$.

PRINCIPE, M. A. (1861 y 62): Fábulas en verso castellano y en variedad de metros. $1^{\text {a }}$ ed. Madrid, Imprenta de D. M. Ibo Alfaro, á cargo de Gomez Vera.

PRÍNCIPE, M. A. (1956): Fábulas de... Barcelona, ed. Molino.

REgÚleZ Y BRAVo, V. (1871): Fábulas de... $2^{4}$ ed. notablemente corregida, aumentada y con un crecido número de asuntos é ilustrada con preciosas láminas. Madrid, Imprenta de J. Limia y G. Urosa.

Rios, A. (1930): Flores Marchitas (poesías). Madrid.

RodaO, J. (1908): Ripios con moraleja. Fabulillas. Segovia, Imp. de «El Adelantado».

Rodriguez Mateo, J. (1921): Fábulas. Ilustraciones de A. Martínez de León. Sevilla, Tipografía Gironés.

RuIZ, JuAN. (Arcipreste de Hita) (1991): Libro de buen amor. Texto íntegro en versión de María Bray Mariño; $1^{\sharp}$ ed; $1^{\star}$ ed. 1965. Madrid, ed. Castalia, «Odres nuevos».

Ruiz Aguilera, V. (1874): Libro de las sátiras. $2^{2} \mathrm{ed} 1^{2}$ ed. Alicante, 1849. Madrid, Imprenta, Estereotipia y Galvanoplastia de Aribau y $\mathrm{C}^{\mathrm{a}}$.

SACRISTÁN, F. (1913): De mi banasta. Madrid, Tip. de la Rev. de Arch., Bibl. y Museos.

SALA, F. J. (1865): Fábulas religiosas y morales en verso castellano y en variedad de metros. Sabadell, Imprenta de D. Pedro Vives.

SALA, F. J. (1886): Nuevas Fábulas. Barcelona, Librería de Juan y Antonio Bastinos, editores.

SALA, F. J. (1887): Espejo moral. Ramillete selecto de Fábulas morales en verso. Barcelona, Librería de Juan y Antonio Bastinos, editores. Biblioteca económica infantil.

Salas, F. G. de: Poesías. Tomo I. Con licencia en Madrid, en la oficina de Ramón Ruiz. Año de MDCCXCVII. Tomo II, id. Incluye: Parábolas morales. Madrid, Imprenta de Villalpando, 1803.

Salas, F. G. de (1827): Colección de los Epígramas, y otras poesías críticas, satíricas y jocosas. $4^{4}$ ed; $1^{2}$ ed. 1806. Madrid, por repullés.

SAMANIEGo, F. M. (1975): Fábulas. Ed., Introducción y notas de Ernesto Jareño. Madrid, ed. Castalia, Col. Clásicos Castalia, $\mathbf{n}^{2} 7$.

SAMANIEGo, F. M. (1995): Las fábulas de... Sus fuentes literarias y emblemáticas. Ed. de Jesús M González de Zárate. Excmo. Ayuntamiento de Laguardia.

Samaniego, F. M.: Fábulas (1997) Edición de Alfonso I. Sotelo. Madrid, Cátedra.

Samaniego, F. M.: Fábulas (1998) Edición de Emilio Martínez Mata. Madrid, Espasa Calpe. Austral, 419.

Selgas y Carrasco, J. (1850): La primavera. Colección de poesías. Prólogo de Manuel Cañete. Madrid, Imprenta de Espinosa y Compañía. $2^{\mathbf{a}}$ ed.: Madrid, Im- 
prenta que fue de Operarios, à cargo de D. F. R. del Castillo, 1853. (Incluye también El Estío).

TORREs, F. (1956): Oid niñas. $9^{a}$ ed. Madrid, Librería y Casa editorial Hernando.

TORRes MUÑoz DE LUNA, R. (1864): El álbum de mis hijos. Poesías dedicadas al Sermo. Sr. príncipe de Asturias. Madrid, Estab. tip. de Antonio Peñuelas.

Trueba, A. de y Pravia, C. de (1879): Fábulas de la educación corregidas y notablemente aumentadas por el primero de sus autores. $2^{\mathrm{a}}$ ed; $1^{\mathrm{a}} \mathrm{Ed}$. 1850. Madrid, Librería de Hernando.

\subsection{Estudios}

Aguilar Piñal, F. (1981-1995): Bibliografía de Autores Españoles del siglo XVIII, Madrid, C.S.I.C.

ARCE, J. (1981): La poesía del siglo ilustrado. Madrid, Alhambra. Estudios.

CIORANESCU, A. (1951): «Sobre Iriarte, La Fontaine y fabulistas en general», Fabulistas literarios, Goya ediciones, Santa Cruz de Tenerife, pp. 3-12. También en: Estudios de Literatura española y comparada, Universidad de La Laguna, 1954, pp. 199-204. COTARELo, E. (1897): Iriarte y su época. Madrid, R. A. E.

Fábulas de Esopo. Vida de Esopo. Fábulas de Babrio (1978), traducción y notas de P. Bádenas y J. López Facal, Introducción de C. G ${ }^{a}$ Gual.. Madrid, Gredos.

CheCA, J.; Ríos, J.A.; Vallejo, I. (1992): La Poesía del Siglo XVIII. Madrid, Júcar. Historia de la Literatura española.

DefourneauX, M. (1973): Inquisición y censura de libros en la España del siglo XVIII. Versión española de J. Ignacio Tellechea Idígoras. Madrid, Taurus.

Diez-CANEDO, E. (Obras de) (1965): Estudios de poesía española contemporánea. México, Joaquín Mortiz.

Garcfa Gual, C. (1995): El zorro y el cuervo. Diez versiones de una famosa fábula. Madrid, Alianza.

GeRmaIN, G. (1933): «La Fontaine et les fabulistes espagnols», Revue de Littérature Comparée, avril-juin (vol. XII), pp. 312-329.

GoYri de MENÉNDEZ PIDAL, M. (Selección, notas y glosario) (1933): Fábulas y cuentos en verso, $2^{\mathrm{a}}$ ed. ( $\left.1^{\mathrm{a}} \mathrm{ed} .1922\right)$. Madrid, Instituto-Escuela. Biblioteca Literaria del estudiante, Tomo $I$.

LÁZARo CARreter, F. (1985): Las ideas lingüísticas en España durante el siglo $X V I I I$. Barcelona, Crítica.

MallorQut, J. (Prólogo, selección y notas) (1956): Fábulas españolas. Barcelona, ed. Molino.

Menéndez Pelayo, M.: Historia de las ideas estéticas en España. Edición Nacional de las obras completas de Menéndez Pelayo dirigida por D. Miguel Artigas. III. Consejo Superior de Investigaciones Científicas, MCMXL. 
MERIMÉ, P. (1936): L'influence française en Espagne au XVIlle siècle. Paris, éd. Les belles Lettres, Études françaises.

Niess, R. J. (1938): «La Fontaine and the Cuentos of Samaniego», Revue de Littérature Comparée, vol. XVIII, pp. 695-701.

NIESS, R. J. (1941): «The pie quebrado in Samaniego's Fables». Hispanic Review. Published by the University of Pennsylvania Press, vol. IX, pp. 304-308.

PALACIOS, E.: (1975): Vida y obra de Samaniego. Vitoria, Biblioteca alavesa «Luis de Ajuria», 13.

Rodríguez AdRADOs, F. (1979-1987): Historia de la fábula greco-latina, 3 Tomos, 4 vols. Madrid, Editorial de la Universidad Complutense.

SAINZ DE Robles, F. C. (Selección, estudio, biografías y notas) (1964): Fabulario español. Madrid, Espasa-Calpe, Austral, $\mathrm{n}^{\circ} 1334$.

VÉzINET, F. (1909): Molière, Florian et la Littérature espagnole. Paris, Hachette. 